\title{
MATRIX FMEA ANALYSIS OF THE FLOW CONTROL VALVE
}

doi: 10.2478/cqpi-2019-0079

Date of submission of the article to the Editor: 22/05/2019

Date of acceptance of the article by the Editor: 31/05/2019

Joanna Fabis-Domagala ${ }^{1}$ - orcid id: 0000-0003-2811-1100

Hassan Momeni' ${ }^{2}$ - orcid id: 0000-0002-3535-5413

Mariusz Domagala ${ }^{1}$ - orcid id: 0000-0001-9642-6142

Grzegorz Filo' ${ }^{1}$ - orcid id: 0000-0003-0848-6124

Saeed Bikass ${ }^{2}$ - orcid id:

Pawel Lempa ${ }^{1}$ - orcid id: 0000-0002-9421-440X

${ }^{1}$ Cracow University of Technology, Institute of Applied Informatics, Jana Pawla II 37, 31-841 Cracow, Poland

${ }^{2}$ Western Norway University of Applied Sciences, Department of Mechanical and Marine Engineering, Inndalsveien 28, 5063 Bergen, Norway

Abstract. Reliability is a key feature in engineering systems and might be improved by using preventive methods, which allows for identification potential failures and establishing cause-and-effect relationships in consistent and systematic way. One of the popular quality improvement method is FMEA (Failure Modes and Effects Analysis). An application of matrix FMEA analysis method on example of flow control valve has been presented and discussed in the work. Presented example shows also a different ways of evaluating failures and theirs influence on analysis results.

Keywords: hydraulic system protection, safety valve, relief valve, FMEA

\section{INTRODUCTION}

Reliability plays an important role in engineering. More and more effort is put on developing methods and tools for identification of potential defects and failures. Improving quality is endless process which involves using efficient tools, which allows to identify failures and undertake preventing actions. One of the earliest methods, developed in 1950s is Failure Mode and Effects Analysis (FMEA), which identify, prioritize and limits failures. FMEA is a type of preventive methods and allows to identify defects and failures also on a design stage and undertake preventive actions to eliminate or minimize risk arisen from those defects and failures. The FMEA might be implemented when defects should be identified as early as possible due to the human health and safety as well as environmental protection. This can be achieved by using FMEA analysis during preliminary design work what allows to obtain information about strengths and weaknesses of the product/process and implement appropriate changes (Hamrol and Mantura, 2004). The FMEA analysis is recognized as one of the main methods of risk management in the automotive industry and is required by the standards for management systems. It is very flexible method, which might be carried 
out for the entire product or process, for a single component of the product or for single operation. There are several types of FMEA methods, e.g.: medical FMEA, FMEA system, FMEA machine or environmental FMEA. However, regarding the way of preparing, conducting and presenting obtained results, the FMEA method can be divided into a sheet analysis (classical) and matrix analysis (Fabis-Domagala, 2027; Filo et al., 2018).

\section{Flow control valve}

Flow control valve main purpose is maintaining constant flow rate regardless the pressure on inlet or outlet. It consists of body with inlet and outlet ports, sleeve, two spools (spool 1 is controlled by the solenoid, spool 2 is responsible for delivery constant flow rate to the outlet), two springs (both are between sleeve and spools) and nonreturn valve. Value of flow rate which is maintained on constant level is set by solenoid acting on spool 1. Pressure at the outlet, along with the spring and throttle valve determine the position of the spool 2.

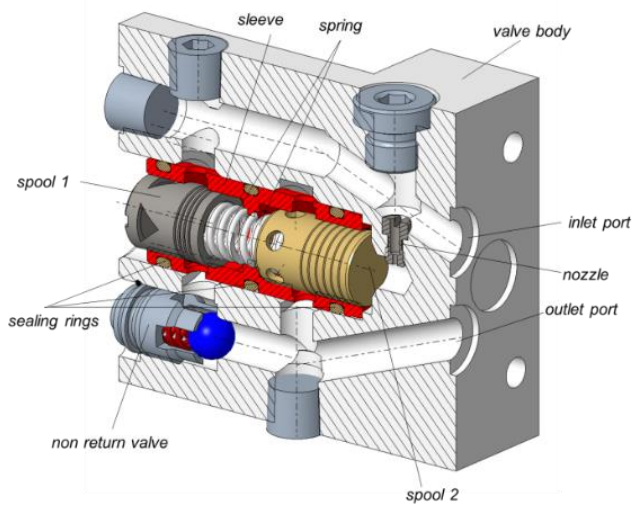

Fig. 1. Flow control valve.

The FMEA analysis includes all components of flow control valve except non return valve.

\section{MATRIX FMEA ANALYSIS OF FLOW CONTROL VALVE}

The FMEA analysis consists of two stages. On the first one, which is recognized as a preparation stage, valve was decomposed into components for which list of failures was prepared as well as functions which those components realize. The matrix of EC and $E F$ is created in this stage. The following components were used in matrix FMEA analysis:

- C1: valve body,

- C2: nozzle,

- C3: sleeve,

- C4: spools (structure and functions of both spools is similar)

- C5: sealing rings,

- C6: springs.

The flow control valve presented in Fig. 1 includes two spools, but due to the similar structure and function which they have in FMEA analysis they were treated as one components. The same approach was used for springs and all sealing rings in the 
sleeve. For above components the following failures were selected: F1: seizure, F2: cracking, F3: wear, F4: clogging, F5: damage.

The matrix CF is presented in Table 1.

Table 1

CF matrix for flow control valve

\begin{tabular}{|c|c|c|c|c|c|}
\hline & F1 & F2 & F3 & F4 & F5 \\
\hline C1 & 0 & 1 & 1 & 0 & 1 \\
\hline C2 & 0 & 1 & 1 & 1 & 1 \\
\hline C3 & 0 & 1 & 1 & 0 & 1 \\
\hline C4 & 1 & 1 & 1 & 0 & 1 \\
\hline C5 & 0 & 1 & 1 & 0 & 1 \\
\hline C6 & 0 & 1 & 0 & 0 & 1 \\
\hline
\end{tabular}

Above matrix was created using the easiest evaluation method. Value 0 is set when failure does not exist for selected component, while value 1 is set when failure exists. At this stage functions for selected components were set as follows:

- E1: fixing: fixing position of valve components ensuring proper flow direction;

- E2: controlling: controlling flow rate in the valve;

- E3: determining pressure difference;

- E4: transferring force.

The matrix EC has the form presented in Table 2. The next step is analysis, which allows to obtain matrix EF (Stock et al., 2003):

$$
\mathbf{E F}=\mathbf{E C} \times \mathbf{C F}
$$

Table 2

EC matrix for flow control valve

\begin{tabular}{|c|c|c|c|c|c|c|}
\hline & C1 & C2 & C3 & C4 & C5 & C6 \\
\hline E1 & 1 & 0 & 1 & 0 & 0 & 0 \\
\hline E2 & 0 & 1 & 0 & 1 & 0 & 0 \\
\hline E3 & 0 & 0 & 1 & 0 & 1 & 0 \\
\hline E4 & 0 & 0 & 0 & 0 & 0 & 1 \\
\hline
\end{tabular}

Table 3

EF matrix for flow control valve

\begin{tabular}{|c|c|c|c|c|c|}
\hline & F1 & F2 & F3 & F4 & F5 \\
\hline E1 & 1 & 3 & 3 & 0 & 3 \\
\hline E2 & 1 & 2 & 2 & 1 & 2 \\
\hline E3 & 0 & 2 & 2 & 0 & 2 \\
\hline E4 & 0 & 1 & 0 & 0 & 1 \\
\hline
\end{tabular}

The EF matrix (Table 3) allows to identify failure which may appear with highest probability. The maximal values of matrix EF is for three failures F2 (cracking), F3 (wear) and F5 (damage) for function E1 (fixing). Above matrix gives not answer which failure is critical (there are three with maximal value), therefore in the next step weighted values of evaluation for selected failures were used:

- 0: failure does not exist;

- 0.25: failure appears incidentally;

- 0.5: failure appears seldom; 
- 0.75: failure appears often;

- 1 :failure appears very often.

The modified matrix Component-Failure (CF) is presented in Table 4. Modified CF matrix multiplied allowed to obtain new Function-Failure (EC) presented in Table 5.

Table 4

Modified CF matrix for weighted evaluation method

\begin{tabular}{|c|c|c|c|c|c|}
\hline & F1 & F2 & F3 & F4 & F5 \\
\hline C1 & 0 & 0.25 & 0.75 & 0 & 0.25 \\
\hline C2 & 0 & 0.25 & 1 & 1 & 0.5 \\
\hline C3 & 0 & 0.25 & 1 & 0 & 0.5 \\
\hline C4 & 1 & 0.25 & 1 & 0 & 0.75 \\
\hline C5 & 0 & 0.5 & 1 & 0 & 0.5 \\
\hline C6 & 0 & 1 & 0 & 0 & 0.5 \\
\hline
\end{tabular}

Table 5

EF matrix for weighted evaluation method for CF matrix

\begin{tabular}{|c|c|c|c|c|c|}
\hline & F1 & F2 & F3 & F4 & F5 \\
\hline E1 & 1 & 0.75 & 2.75 & 0 & 1.5 \\
\hline E2 & 1 & 0.5 & 2 & 1 & 1.25 \\
\hline E3 & 0 & 0.75 & 2 & 0 & 1 \\
\hline E4 & 0 & 1 & 0 & 0 & 0.5 \\
\hline
\end{tabular}

The maximal value is obtained for failure F3 (wear), however various types of wear are met in hydraulic valves. The following wear type were selected for flow control valve: F31 - abrasive wear, F32 - corrosive wear, F33 - erosive wear, F34 - sliding wear. On this stage of analysis new matrix was created only for wear failure. CF3 matrix (Table 6) for wear failure was created with the use of 0-1 value.

After multiplication of EC with CF3 we obtain EF3 matrix presented in Table 7.

Table 6

CF3 matrix for wear failure

\begin{tabular}{|c|c|c|c|c|}
\hline & F31 & F32 & F33 & F34 \\
\hline C1 & 0 & 1 & 1 & 0 \\
\hline C2 & 0 & 1 & 1 & 0 \\
\hline C3 & 1 & 1 & 1 & 1 \\
\hline C4 & 1 & 1 & 1 & 1 \\
\hline C5 & 0 & 0 & 0 & 0 \\
\hline C6 & 0 & 0 & 0 & 0 \\
\hline
\end{tabular}

Table 7

EF3 matrix for wear failure

\begin{tabular}{|c|c|c|c|c|}
\hline & F31 & F32 & F33 & F34 \\
\hline E1 & 2 & 3 & 3 & 2 \\
\hline E2 & 1 & 2 & 2 & 1 \\
\hline E3 & 1 & 1 & 1 & 1 \\
\hline E4 & 0 & 0 & 0 & 0 \\
\hline
\end{tabular}

Evaluation method based only on two values ( 0 or 1$)$ does not allow to indicate which type of wear is dominant, two types have the maximal values: F32 (corrosive wear) and 
F33 (erosive wear). To find which wear type is dominant a weighted values were used with scale as before. The new CF3 matrix with weighted value is shown in Table 8. And finally new EF3 matrix is presented in Table 9.

Table 8

CF3 matrix for weighted wear failure.

\begin{tabular}{|c|c|c|c|c|}
\hline & F31 & F32 & F33 & F34 \\
\hline C1 & 0 & 0.25 & 0.75 & 0 \\
\hline C2 & 0 & 0.25 & 0.75 & 0 \\
\hline C3 & 0.75 & 0.25 & 0.75 & 1 \\
\hline C4 & 0.75 & 0.25 & 0.75 & 1 \\
\hline C5 & 0 & 0 & 0 & 0 \\
\hline C6 & 0 & 0 & 0 & 0 \\
\hline
\end{tabular}

Table 9

EF3 matrix for weighted wear failure.

\begin{tabular}{|c|c|c|c|c|}
\hline & F31 & F32 & F33 & F34 \\
\hline E1 & 1.5 & 0.75 & 2.25 & 2 \\
\hline E2 & 0.75 & 0.5 & 1.5 & 1 \\
\hline E3 & 0.75 & 0.25 & 0.75 & 1 \\
\hline E4 & 0 & 0 & 0 & 0 \\
\hline
\end{tabular}

Above matrix indicates failure F33 (erosive wear) as a type of wear with highest probability of occurrence. This is confirmed by experience as a one of the typical wear of spool type of fluid power valves. Obtained results allows also to define preventive measures, which may be taken also on design stage. With help of design tolls like CAE (Computer Aided Engineering) a conditions in which erosive wear may appear might be determined. Authors showed (Domagala et al., 2018a; Domagala et al., 2018b) CFD simulations for flow control valve aimed at evaluation of erosive wear caused by cavitation or flow of fluid with solid particles.

\section{CONCLUSIONS}

Reliability of flow control valve might be improved by using matrix FMEA analysis which was presented in this work. Performed analysis allowed to obtain information about possible failures which may appear during fluid flow in the valve. However, matrix FMEA analysis had to be performed in few steps due to the fact that evaluation method have a significant influence on analysis results. The easiest way of failure evaluation, which base on two states: failure exist or does not exist may give results which are not able to identify failure with the highest probability of occurrence. More detailed results may be achieved by using more sophisticated evaluation method, however, it required wide knowledge in field of possible failures and damages of investigated component or system. Matrix FMEA analysis may by supported by other design tools or knowledge base to define potential failures which may appear or probability of failures occurrence. The approach presented in this paper may be also useful for researchers in other area because it is strong tool (Kielbus and Karpisz, 2019) for significant quality improvement in a management (Kozien and Kozien, 2017; Maszke et al., 2018) as well as in biotechnology (Skrzypczak-Pietraszek and Pietraszek, 2012), materials science 
(Korzekwa et al., 2014; Lipinski, 2015), machine design (Pacana and Pacana, 2018; Karpisz and Kielbus, 2019).

\section{REFERENCES}

Hamrol, A., Mantura, W., 2004. Quality management. Theory and practice. Zarządzanie jakością. Teoria i praktyka, Warszawa, PWN [in Polish].

Fabis-Domagala, J., 2017. Analysis of defects and failures of hydraulic gear pumps with the use of selected qualitative methods, Tribiologia, 2/2017, 33-38.

Filo, G., Fabis-Domagala, J., Domagala, M., Lisowski, E., Momeni, H., 2018. The idea of fuzzy logic usage in a sheet-based FMEA analysis of mechanical systems. MATEC Web Conf., 183, art. 03009. DOI: 10.1051/matecconf/201818303009

Stock, M.E., Stone, R.B., Tumer, I.Y., 2003. Going back in time to improve design: the elemental function-failure design method. DETC'03 ASME 2003 Design Engineering Technical Conference, Computers and Information in Engineering Conference, Chicago, ASME.

Domagala, M., Momeni, H., Domagala-Fabis, J., Filo, G., Krawczyk, M., 2018a. Simulation of Cavitation Erosion in a Hydraulic Valve. Materials Research Proceedings, 5, 1-6. DOI: 10.21741/9781945291814-1

Domagala, M., Momeni, H., Domagala-Fabis, J., Filo, G., Kwiatkowski, D., 2018b. Simulation of Particle Erosion in a Hydraulic Valve. Materials Research Proceedings, 5, 17-24. DOI: 10.21741/9781945291814-4

Karpisz, D., Kielbus, A., 2019. The Revitalization of Radar System as a Case of Functional and Information Security Problems. System Safety: Human - Technical Facility - Environment, 1, 692-699. DOI: 10.2478/czoto-2019-0088

Kielbus, A., Karpisz, D., 2019. Risk management as a process security tool. System Safety: Human-Technical Facility-Environment, 1, 234-239. DOI: 10.2478/czoto2019-0030

Korzekwa, J., Skoneczny, W., Dercz, G., Bara, M. Wear mechanism of $\mathrm{Al}_{2} \mathrm{O}_{3} / \mathrm{WS}_{2}$ with PEEK/BG plastic. J. Tribol.-T. ASME 2014, vol. 136, art. 011601. DOI: $10.1115 / 1.4024938$

Kozien, E., Kozien, M.S., 2017. Interval analysis as a method of measurement of uncertainity in the check-list method applied to identification of stage phase of companies. $26^{\text {th }}$ Int. Scientific Conf. Economic and Social Development. Zagreb, Varazdin, 210-215.

Lipinski, T., 2015. Double modification of AlSigMg alloy with boron, titanium and strontium. Arch. Metall. Mater., 60, 2415-2419. DOI: 10.1515/amm-2015-0394

Maszke, A., Dwornicka, R., Ulewicz, R., 2018. Problems in the implementation of the lean concept at a steel works - Case study. MATEC Web Conf., vol. 183, art. 01014. DOI: $10.1051 /$ matecconf $/ 201818301014$

Pacana, J., Pacana, A., 2018. Analysis of Possibilities of Using Polymeric Materials for Testing Prototypes of Harmonic Drive. Materials Research Proceedings, 5, 61-66. DOI: 10.21741/9781945291814-11

Skrzypczak-Pietraszek, E., Pietraszek, J., 2012. Chemical profile and seasonal variation of phenolic acid content in bastard balm (Melittis melissophyllum L., Lamiaceae). Journal of Pharmaceutical and Biomedical Analysis, 66, 154-161. DOI: 10.1016/j.jpba.2012.03.037 